\title{
SPOTTED REDSHANK SIGHTED NEAR REGINA
}

JOHN F. NELSON, 26 Lawson Street, Regina, Saskatchewan. S4R 3P7

On 30 July 1990, my 14-year-old grandson and I were checking shorebirds at Brown's Slough, a favourite location some $10 \mathrm{~km}$ northwest of Regina. We identified the usual variety for that area such as Greater and Lesser Yellowlegs, Willets, Marbled Godwits and some Peeps, when Stephen said, "Grandpa, there's a 'different' bird out there." I suggested that it was probably a Greater Yellowlegs, but he brought me up short by saying, "This one has red legs."

This particular shorebird was feeding somewhat apart from the other birds in that section of the slough - in tall grass in about ten $\mathrm{cm}$ of water. When we scoped the bird, the red legs were unmistakable. Other features that caught our attention were the light-coloured basal part of the lower mandible, a lightcoloured lower forehead, and Stephen also noted a slight downward curve of its beak.

We checked the various bird guides we had with us but couldn't quite make up our minds until we looked at Godfrey's Birds of Canada. ${ }^{1}$ There on the bottom of Plate 27 was our bird - a Spotted Redshank (Tringa erythropus), in winter plumage.

What made this bird particularly exciting was the fact that there were no records for the Canadian interior. Godfrey lists its status as "...several sight records for British Columbia, a sight record for Newfoundland..." and two records for Ontario. The National Geographic Society lists it as a "rare spring and fall visitor to Aleutians and Pribilofs; casual on both coasts during migration and winter." 3 Peterson lists records from Ontario, Newfoundland, Connecticut, Rhode Island and Pennsylvania. $^{2}$

Frank Brazier checked his copies of American Birds and found a reference to this species as having been noted at Las Vegas, Nevada, from 16-20 August 1975 (Am. Birds 30:102).

Brazier and I checked the slough later in the day, but our bird was gone.

Stephen and I returned to Brown's Slough the day following our sighting, but our bird had disappeared. This was an unforgettable experience equally for Stephen who has just started in this fascinating hobby, and for myself who has spent some 60 years pursuing birds.

1. GODFREY, W.E. 1986. The birds of Canada. Natl. Mus. Canada, Ottawa. 595 pp.

2. PETERSON, R.T. 1980. Field guide to the birds of eastem and central North America. Houghton Mifflin, Boston. 384 pp.

3. SCOTT, S.L. 1987. Field guide to the birds of North America. Natl. Geographic Soc., Washington, D.C. 464 pp. 